Acta vet. scand. $1988,29,15-22$.

From the Department of Food and Environmental Hygiene, College of Veterinary Medicine, the Computing Service, Technical Research Centre of Finland, and the Veterinary Department, Ministry of Agriculture and Forestry, Helsinki, Finland.

\title{
The Effect of the pH of Meat on the Boiling Test
}

\author{
By H. Korkeala, T. Alanko, O. Mäki-Petäys, and O. Sorvettula
}

\begin{abstract}
Korkeala, H., T. Alanko, O. Mäki-Petäys and O. Sorvettula: The effect of the pH of meat on the boiling test. Acta vet. scand. 1988, 29, 15-22. - The effect of the $\mathrm{pH}$ on the boiling test was studied in 68 beef and 108 pork muscles. The pH had a significant effect on the sensory scores obtained from the boiling test. The effect was particularly pronounced in the odour of meat. In beef the odour scores remain steady for samples with a pH value under about 6.2 and start to increase rapidly in higher $\mathrm{pH}$ values. In pork the increase in scores appears to be linear. The odour observed in high $\mathrm{pH}$ meat was described by the judges as abnormal and ammonialike. In the case of meat with a high $\mathrm{pH}$, the results of the boiling test at meat inspection should be interpreted with extreme caution.
\end{abstract}

meat inspection; beef; pork; odour; appearance; odour of meat; appearance of meat; quality; meat quality.

\section{Introduction}

A boiling test is used very commonly at meat inspection to evaluate possible abnormal odours in carcasses. Abnormal odours may be acquired from outside sources such as the consumption of certain food stuffs, from drugs or by absorption of strong-smelling substances during storage. Abnormal odours may also be due to disease. The presence of abnormal odours in the boiling test can cause the condemnation of the carcass (Gracey 1981).

It is known that $\mathrm{pH}$ has an effect on the colour (Bouton \& Shorthose 1969), flavour (Park \& Murray 1975, Lawrie 1985), spoilage (Gill \& Newton 1979, Grau 1981), tenderness and water-holding capacity of meat (Bouton et al. 1971, Bouton et al. 1972, Bouton et al. 1973 a, Bouton et al. 1973 b). Meat inspectors also think that high ultimate $\mathrm{pH}$ of meat may cause abnormal odours, disturbing the interpretation of the boiling test, al- though to our knowledge there are no reports concerning the subject. The present study was undertaken to determine the possible effect of the $\mathrm{pH}$ on the boiling test.

\section{Materials and methods Sampling}

Thirty-four beef muscle samples from both M. triceps brachii caput longum (MT) and $M$. adductor (MA) and 54 pork muscle samples from both MT and MA were taken about $62 \mathrm{~h}$ (range 24-180 h) after slaughter. The $\mathrm{pH}$ of the samples was measured and the boiling test was carried out immediately after sampling.

\section{Measurement of the $\mathrm{pH}$}

The $\mathrm{pH}$ of the samples was measured directly from the muscles (ISO 1974, Anon. 1982 a) by the combined electrode with needle-shaped membrane for puncture measurements (Ingold 404-T, Dr. W. Ingold AG, 
Zurich, Switzerland) using the Knick 742 Microprocessor $\mathrm{pH}$ meter (Knick Elektronische Messgeräte GmbH \& Co, Berlin) with the Knick 6929 Thermocompensator probe. The meat used for the measurement was free of fat and connective tissue.

The measurement was carried out at least twice for each sample and the figure used was the arithmetic mean of the $\mathrm{pH}$ values obtained. The electrode was cleaned after each measurement and the meter calibration was checked at regular intervals. For details see Korkeala et al. (1986).

\section{The boiling test}

The odour and appearance of the meat and of the liquid in which the meat was boiled were evaluated using a scoring from 1 to 4 according to the official Finnish method (Anon. 1982 b). A score of 1 was given when the odour or appearance of the meat or of the boiling liquid was normal and a score of 4 was given when the odour or appearance was strongly changed. Descriptive terms accompanying the numerical scores were given to the judges. When high scores were given the reason had to be stated.

The judges had been trained for this task and they were familiar with off-flavour problems. The sensitivity of taste and smell of the judges had been checked. The number of judges was 3-5.

An arithmetic mean was calculated from the scores given by the different judges for all 4 evaluated properties of the meat samples. In the subsequent analysis these mean scores are compared with the $\mathrm{pH}$ values.

\section{Statistical analysis}

In the statistical analysis the main emphasis was on the visual examination of the scatter diagrams where the sensory evaluation scores were plotted against the $\mathrm{pH}$ values. These examinations were complemented with stati- stical methods where the mean scores were treated as interval scale variables. The methods used included linear and nonlinear regression models. All the calculations were performed using the BMDP statistical software (BMDP 1983) on a Cyber-180 mainframe computer.

\section{Results}

All the numerical statistical results are presented in Tables 1 and 2 and in the Appendix. The tables include descriptive statistics and correlations between different scores and the $\mathrm{pH}$. The fitted equations for the associations between the $\mathrm{pH}$ and the scores are given in the Appendix.

Table 1. Descriptive statistics for the $\mathrm{pH}$ of the samples.

\begin{tabular}{lrcc}
\hline Samples & $\mathrm{n}$ & Mean & $\mathrm{SD}$ \\
\hline All samples & 176 & 5.8 & 0.41 \\
Beef samples & 68 & 5.7 & 0.41 \\
Pork samples & 108 & 5.9 & 0.40 \\
Samples with & & & \\
ammonia-like odour & 39 & 6.4 & 0.34 \\
Samples without & & & \\
ammonia-like odour & 137 & 5.7 & 0.30 \\
\hline
\end{tabular}

Table 2. Correlations between sensory evaluation scores and the $\mathrm{pH}$.

\begin{tabular}{llll}
\hline $\begin{array}{l}\text { Sensory } \\
\text { evaluation }\end{array}$ & $\begin{array}{l}\text { Overall } \\
\mathrm{pH}\end{array}$ & $\begin{array}{l}\mathrm{pH} \text { in } \\
\text { beef } \\
\text { samples }\end{array}$ & $\begin{array}{l}\mathrm{pH} \text { in } \\
\text { pork } \\
\text { samples }\end{array}$ \\
\hline $\begin{array}{l}\text { Odour of meat } \\
\text { Appearance of } \\
\text { meat }\end{array}$ & $0.62^{* *}$ & $0.67^{* * \mathrm{~b}}$ & $0.57^{* *}$ \\
$\begin{array}{l}\text { Odour of boiling } \\
\text { liquid }\end{array}$ & $0.43^{* *}$ & $0.39^{* *}$ & $0.41^{* *}$ \\
$\begin{array}{l}\text { Appearance of } \\
\text { boiling liquid }\end{array}$ & $0.25^{* *}$ & $0.39^{* * \mathrm{~b}}$ & $0.21^{*}$ \\
\hline
\end{tabular}

** = statistically significant at the $p<0.01$ level

b These correlations do not give a correct picture of the association since the relationship is non-linear. See Appendix.

* = statistically significant at the $p<0.05$ level $\mathrm{NS}=$ not statistically significant, $\mathrm{p}>0.05$. 


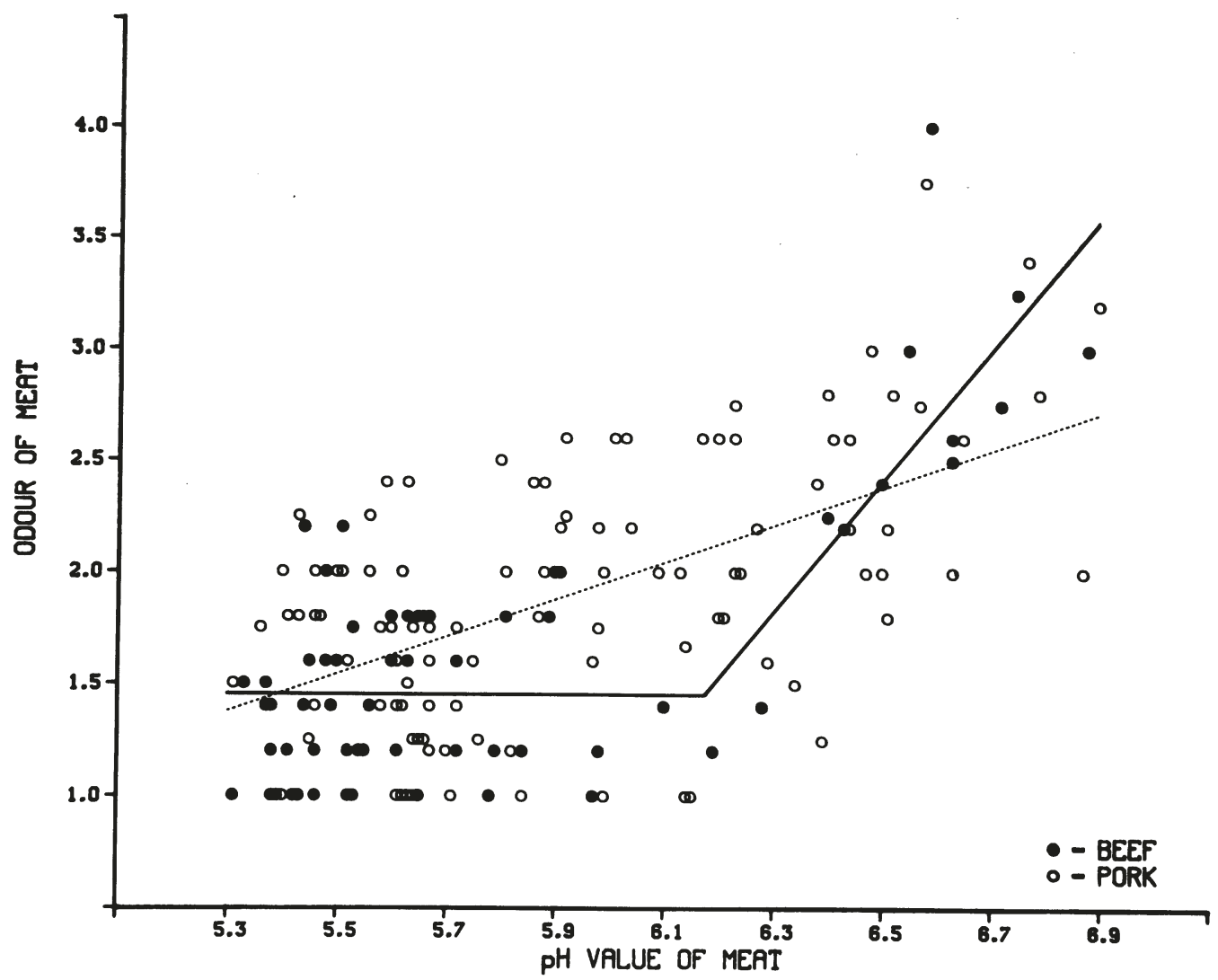

Figure 1. Scatter diagram and estimated equations (see Appendix) between odour scores for the meat and $\mathrm{pH}$. Continuous line stands for beef and dotted line for pork.

\section{Odour of meat}

The relationship between the $\mathrm{pH}$ and odour scores of the meat samples is presented as a scatter diagram in Fig. 1. The scores related to odours of the meat samples appear to increase with the $\mathrm{pH}$. However, the beef and pork samples behave somewhat differently. In beef the odour scores remain on the same level until the $\mathrm{pH}$ of meat samples is about 6.2 and starts to increase after that. In pork the increase appears to be linear. To assess these findings statistically, ordinary correlation coefficients were first calculated and their significance against the null hypothesis of zero correlation tested (Table 2). Then, the linearity of the association was tested by fitting sequential polynomial regression models and testing the appropriate order of the polynomial by the nested F-test technique. In the beef samples the linearity of the dependency was rejected but not in pork. Thus, for pork, a linear regression model was fitted to data (and shown by the dotted line in Fig. 1). For beef, a changing regime (see e.g. Goldfeld \& Quandt 1972) regression model was fitted. The model best descriptive of the data is one where the scores remain on a level up to a turning point (estimated $\mathrm{pH}$ 
value 6.17) and then start to increase. The fitted model is shown as a continuous line in Fig. 1. For the fitted models see Appendix. The judges considered the odour observed at a high $\mathrm{pH}$ abnormal, and gave high scores. It was described by the judges as an ammonialike odour. The mean $\mathrm{pH}$ of the meat samples $(n=39)$ in which this ammonia-like odour was observed by the judges was 6.37 (Table 1). The mean $\mathrm{pH}$ of the samples $(n=137)$ in which no ammonia-like odour was found was 5.71 .

\section{Appearance of meat}

Appearance-of-meat scores are shown against the $\mathrm{pH}$ values in Fig. 2. For both beef and pork samples there is a very slight but statistically significant linear dependency between the scores and the $\mathrm{pH}$ (Table 2 and Appendix). The corresponding fitted regression lines are also shown in Fig. 2, the continuous line representing beef and the dotted line pork.

In some cases of high $\mathrm{pH}$, red areas were also observed in the meat samples. This was not, however, considered to constitute a strongly abnormal appearance and the judges did not assign high scores for this.

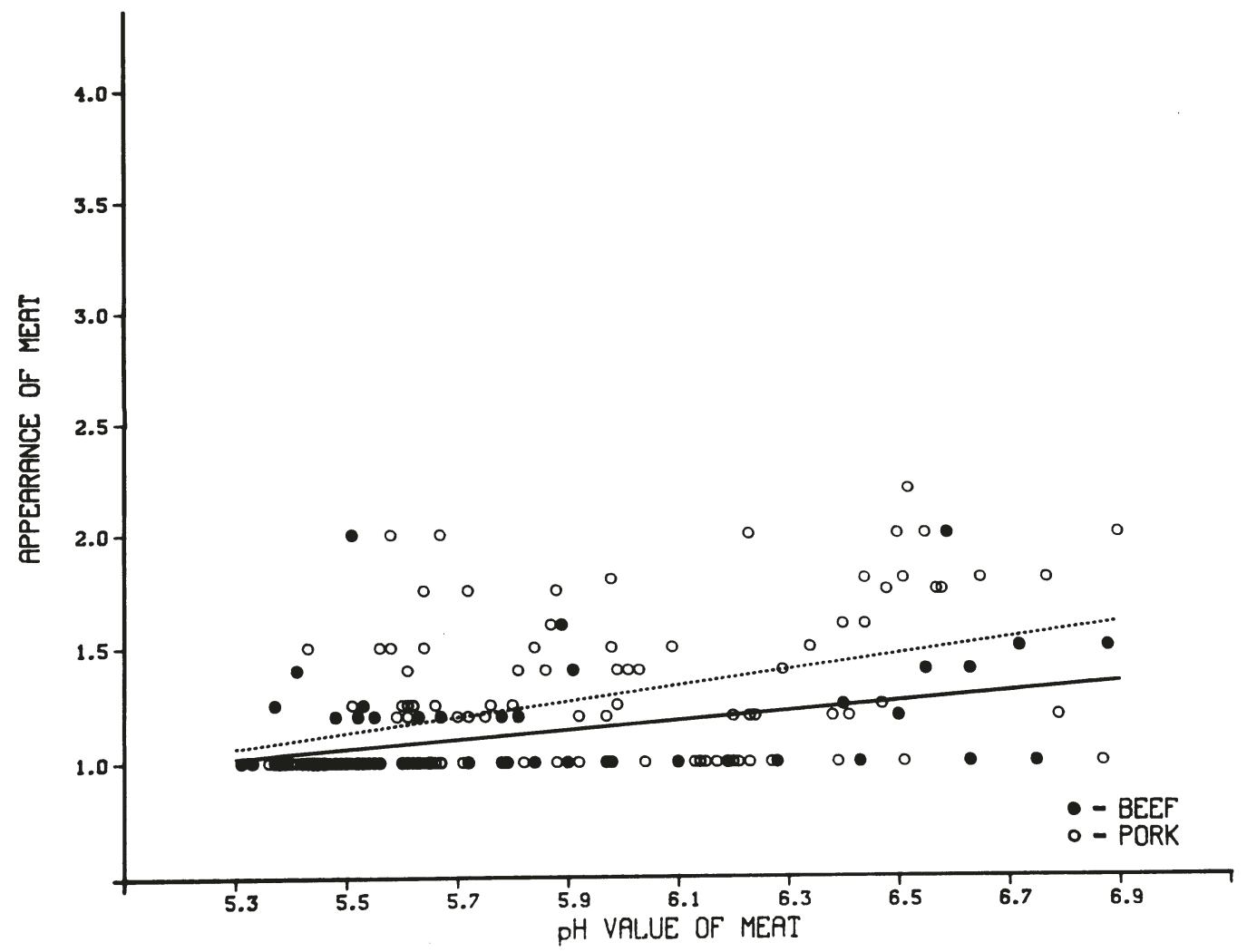

Figure 2. Scatter diagram end estimated equations (see Appendix) between appearance scores for meat and pH. Continuous line stands for beef and dotted line for pork. 


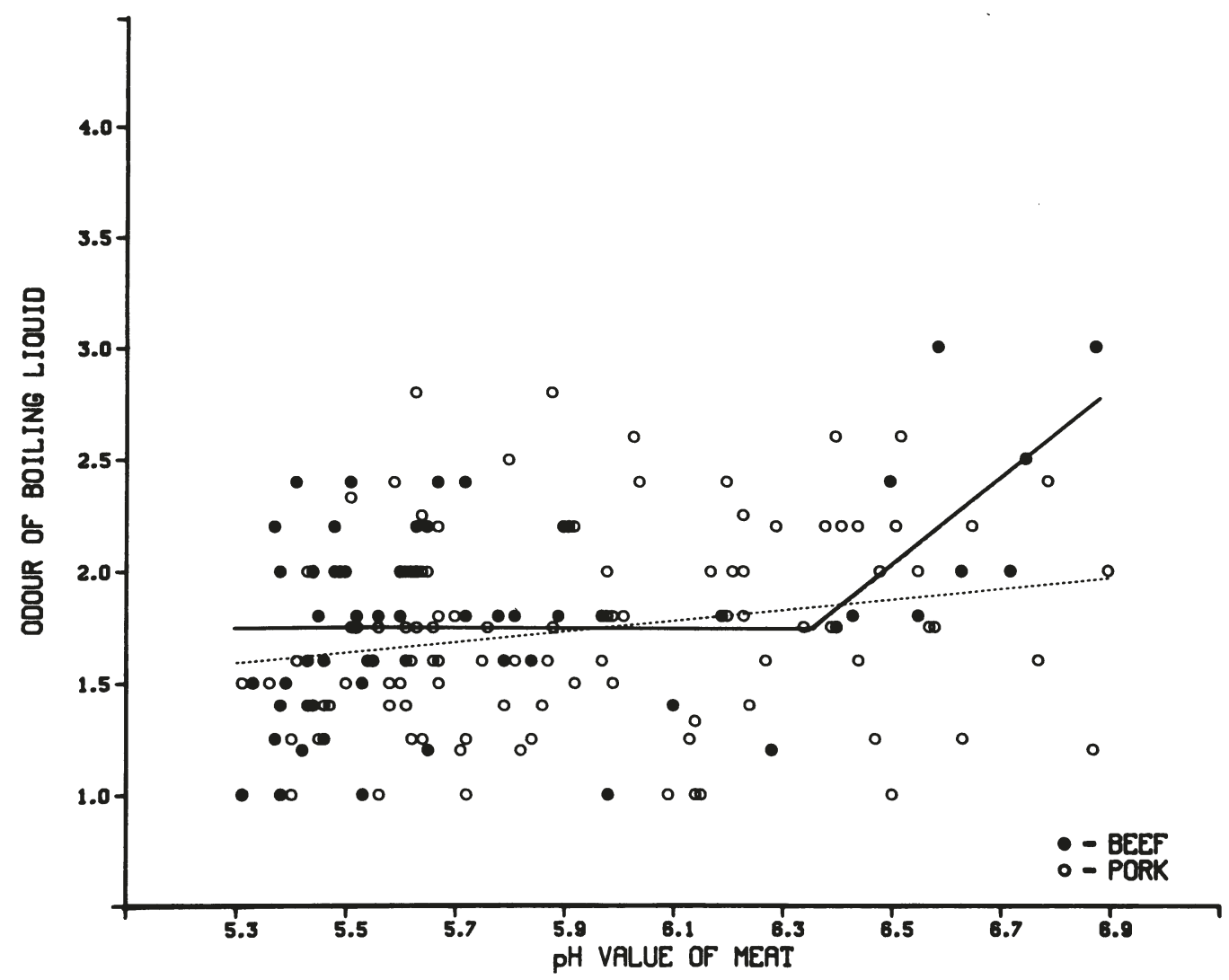

Figu r e 3. Scatter diagram and estimated equations (see Appendix) between odour scores for boiling liquid and $\mathrm{pH}$ of meat. Continuous line stands for beef and dotted line for pork.

\section{Odour of boiling liquid}

Scores for the odour of the boiling liquid depend on the $\mathrm{pH}$ in much the same manner as the scores for the odour of meat (Fig. 3). Again, the dependency of the beef scores on the $\mathrm{pH}$ is nonlinear and that of the pork scores is linear. However, the increase in the scores due to the $\mathrm{pH}$ is lesser than in the case of odour of meat. Using the same statistical techniques as for odour of meat, a changing parameter model with an estimated turning point at $\mathrm{pH}$ value 6.36 was fitted to the beef samples. A linear model was fitted to the pork samples (Table 2 and Appendix). Both are shown in Fig. 3.

\section{Appearance of boiling liquid}

The appearance scores of the boiling liquid are low and seem not to be related to $\mathrm{pH}$ (Fig. 4). However, a small but statistically significant increase was found for the pork samples. 


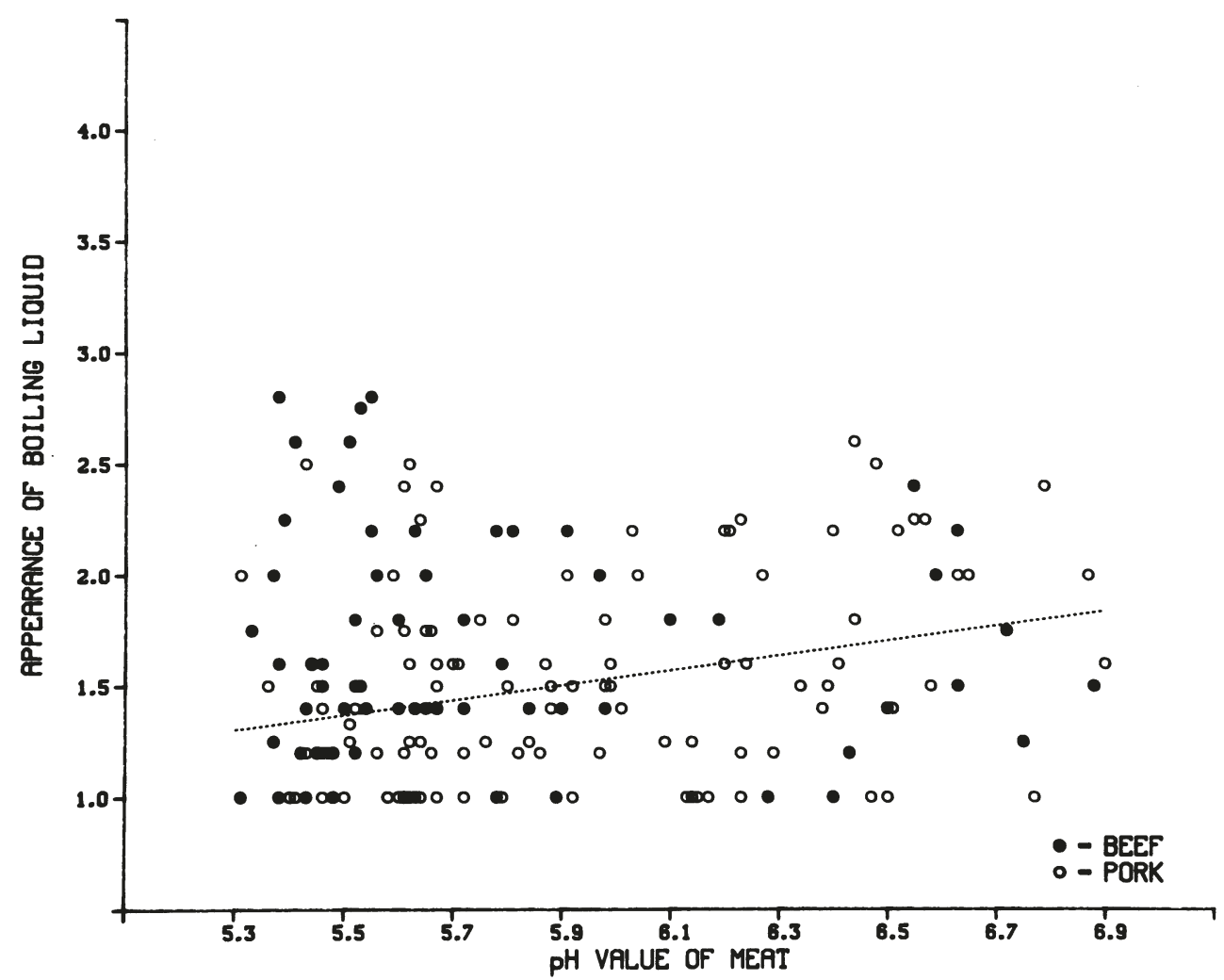

Figure 2. Scatter diagram end estimated equations (see Appendix) between appearance scores for meat and pH. Continuous line stands for beef and dotted line for pork.

\section{Discussion}

The $\mathrm{pH}$ has an effect on the scores obtained from the boiling test. This effect is marked in beef in the case of the odour of the meat and the odour of the boiling liquid. The effect of the $\mathrm{pH}$ in beef starts to show first when the $\mathrm{pH}$ of the sample is over 6.2 for the odour of meat and over 6.4 for the odour of boiling liquid. In beef a slight linear increase can also be observed in the appearance of meat. In pork, the effect of the $\mathrm{pH}$ on the sensory score is, in general, linear and is marked in the odour of meat. A slight dependency can be observed in the appearance of the meat. The changes due to the $\mathrm{pH}$ in the boiling liquid scores for pork are slight. The odour observed in high $\mathrm{pH}$ meat was described by the judges as ammonia-like.

The ammonia-like odour was strong and was considered to differ from the odour of normal meat. The flavour intensity is also found to decrease with increase of the ultimate $\mathrm{pH}$ of meat (Lawrie 1985). Park \& Murray (1975) reported that meat exhibiting high ultimate $\mathrm{pH}$ values possesses flavour properties markedly different from meat of normal $\mathrm{pH}$.

The finding that the odour observed in high $\mathrm{pH}$ meat might be due to ammonia is in accordance with the results of Hornstein et al. 
(1960), Yueh \& Strong (1960), Gorbatov \& Lyaskovskaya (1980) and Ford \& Park (1980) who associated ammonia with meat flavour in both beef and pork. Hornstein et al. (1960) and Yueh \& Strong (1960) found that the volatile fraction from lean beef cooked in boiling water contained ammonia. The odour of ammonia was observed after treatment of sodium hydroxide. Ford \& Park subsequently suggested that ammonia is characteristic for high ultimate $\mathrm{pH}$ meat. The cooking of raw ham causes also an increase in ammonia (Gorbatov \& Lyaskovskaya 1980). However, the intensity of the odour observed in the present study was so strong and undesirable that the acceptability of the meat was clearly reduced.

The ammonia-like odour due to a high $\mathrm{pH}$ could be confused with the abnormal odours caused by diseases or an outside source and the meat might thus be condemned. However, there is no legitimate reason to consider such meat unfit for human consumption. Due to its low acceptability such meat should be used in processed meat products. Our findings show that extraordinary carefulness has to be followed in the interpretation of the boiling test of high $\mathrm{pH}$ meat.

\footnotetext{
Appendix

Equations describing the dependency of the sensory scores on the $\mathrm{pH}$.

We denote the scores by $y$ in the equations. All the equations have been estimated by using the least squares fit. The numbers in parentheses indicate estimated standard deviations of the parameter estimates. In the two changing regime models these standard deviation estimates are asymptotic.
}

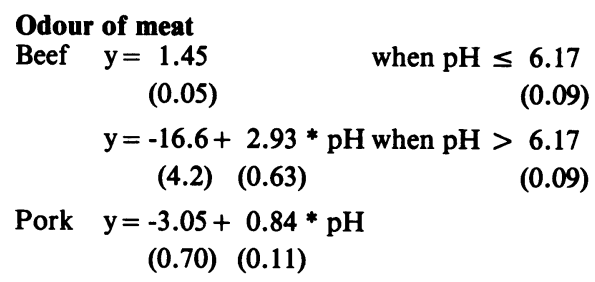

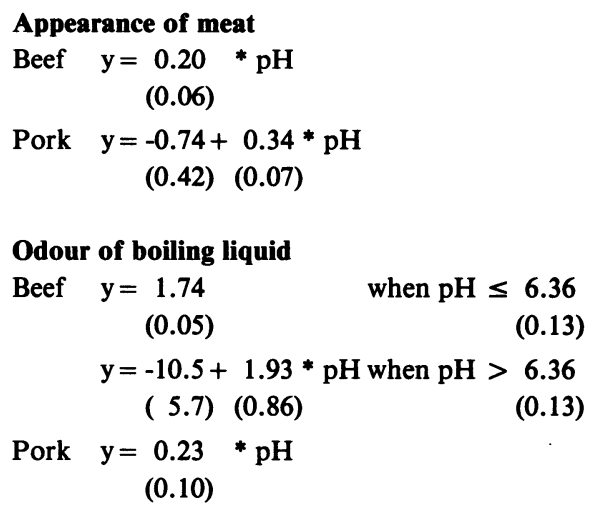

\section{Appearance of boiling liquid}

Beef

Pork $\mathrm{y}=0.33 * \mathrm{pH}$

(0.10)

\section{References}

Anon.: Lihan pH:n mittaaminen. (Determination of pH in meat). Circular No. 201, Veterinary Department, Ministry of Agriculture and Forestry, Helsinki, 1982 a.

Anon.: Keittokoe lihantarkastuksessa. (Boiling test at meat inspection). Circular No. 200, Veterinary Department, Ministry of Agriculture and Forestry, Helsinki, 1982 b.

BMDP: BMDP Statistical Software, University of California Press, Los Angeles 1983.

Bouton PE, Carroll FD, Fischer AL, Harris PV, Shorthose WR: Effect of altering ultimate $\mathrm{pH}$ on bovine muscle tenderness. J. Fd. Sci. 1973 a, 38, 816-820.

Bouton PE, Carroll FD, Harris PV, Shorthose WR: Influence of $\mathrm{pH}$ and fiber contraction state upon factors affecting the tenderness of bovine muscle. J. Fd. Sci. 1973 b, 38, 404-407.

Bouton PE, Harris PV, Shorthose WR: Effect of ultimate $\mathrm{pH}$ upon the water-holding capacity and tenderness of mutton. J. Fd. Sci. 1971, 36, 435439.

Bouton PE, Harris PV, Shorthose WR: The effects of ultimate $\mathrm{pH}$ on ovine muscle: water-holding capacity. J. Fd. Sci. 1972, 37, 351-355. 
Bouton PE, Shorthose WR: Correlations between ultimate $\mathrm{pH}$ and some quality traits of sheep meat. Proc. 15th Meeting Eur. Meat Res. Wkrs., Helsinki 1969, p. 78-83.

Ford AL, Park RJ: Odours and flavours in meat. In: Developments in Meat Science, Vol. I. Ed. R. A. Lawrie, Applied Science Publishers, London 1980, pp. 219-248.

Gill CO, Newton KG: Spoilage of vacuum-packaged dark firm, dry meat at chill temperatures. Appl. Environ. Microbiol. 1979, 37, 362-364.

Goldfeld SM, Quandt RE: Nonlinear Methods in Econometrics. North-Holland Publishing Company, Amsterdam 1972.

Gorbatov VM, Lyaskovskaya YN: Review of the flavour-contributing volatiles and water-soluble non-volatiles in pork meat and derived products. Meat Sci. 1980, 4, 209-225.

Grau FH: Role of $\mathrm{pH}$, lactate and anaerobiosis in controlling the growth of some fermentative gram-negative bacteria on beef. Appl. environ. Microbiol. 1981, 42, 1043-1050.

Gracey JF: Thornton's Meat Hygiene. Baillière Tindall, London 1981.

Hornstein I, Crowe PF, Sulzbacher WL: Constituents of meat flavor: Beef. J. Agric. Fd Chem. $1960,8,65-67$.

ISO: Meat and meat products. Measurement of $\mathrm{pH}$ (reference method) ISO 2917, International Organisation for Standardisation, Geneva 1974.

Korkeala H, Mäki-Petäys O, Alanko T, Sorvettula $O$ : Determination of $\mathrm{pH}$ in meat. Meat Sci. 1986, 18, 121-132.
Lawrie RA: Meat Science. Pergamon Press, Oxford 1985.

Park RJ, Murray KE: High pH meat. Meat Res. in C.S.I.R.O. 1975 p. 22.

Schönberg F, Zietzschmann O: Die Ausführung der tierärztlichen Fleischuntersuchung. (The Practice of Veterinary Meat Inspection). Verlag Paul Parey, Berlin 1958.

WHO: Join FAO/WHO expert committee on meat hygiene. Wld Hlth Org. tech. Rep. Ser. No. 99, World Health Organisation, Geneva 1955.

Yueh MH, Strong FM: Some volatile constituents of cooked beef. J. Agric. Fd Chem. 1960, 8, 491494.

\section{Sammanfattning}

Effekten av köttets pH pả kokprovet.

Effekten av pH på kokprovet undersöktes i muskler av 68 nöt och 108 svin. pH hade en anmärkningsvärd effekt på de sensoriska värderingspoäng som erhölls vid kokprovet. Effekten var speciellt märkbär i köttets lukt. Luktpoängen var jämna i de nötprov, vilkas $\mathrm{pH}$-värde var under 6.2. När pH-värdet var över 6.2 började luktpoängen stiga snabbt. Stegringen av luktpoängena i svinmuskulatur ser ut att vara lineär. Bedömarna beskrev lukten som observerades vid köttets höga $\mathrm{pH}$-värden som onormal och ammoniakliknande. När pH-värdet i kött är högt, bör resultaten av kokprovet i köttbesiktningen tolkas speciellt försiktigt.

(Received July 9, 1987).

Reprints may be requested from: H. Korkeala, Department of Food and Environmental Hygiene, College of Veterinary Medicine, P. O. Box 6, 00551 Helsinki, Finland. 